\title{
The Development of Diets to Induce Atherogenic Lipid Profiles for Cynomolgus Monkeys in Their Country of Origin
}

\author{
Dewi Apri Astuti ${ }^{1,2, *}$, Dondin Sajuthi ${ }^{1}$, Irma Herawati Suparto ${ }^{1}$, Jay Kaplan ${ }^{3}$, Sue Appt ${ }^{3}$, Thomas B. Clarkson ${ }^{3}$ \\ ${ }^{1}$ Primate Research Center, Bogor Agricultural University, Bogor, Indonesia \\ ${ }^{2}$ Department of Animal Nutrition Bogor Agricultural University, Bogor, Indonesia \\ ${ }^{3}$ Centre for Comparative Medicine Research, Wake Forest School of Medicine, Winston Salem, NC. USA \\ *Corresponding author: dewiapriastitu86@gmail.com
}

Received July 24, 2014; Revised October 05, 2014; Accepted October 10, 2014

\begin{abstract}
Understanding the process of atherosclerosis progress can be studied in laboratory animals, such as nonhuman primate (NHP). Investigators at Bogor Agricultural University Indonesia, Primate Research Center (IPB) reported to develop an atherogenic diet (IPB 1) by using fresh egg yolk and coconut oil as source of cholesterol and fat. The aims of the research were to correct nutritional inadequacy in the initial IPB 1 atherogenic diet by supplementation with corn oil (IPB 1+CO); to use dry powdered egg yolk (PEY) instead of fresh egg yolk (IPB $1+\mathrm{CO}+\mathrm{PEY}$ ); to use concentrated source of protein (43\%) pupae meal (PM) instead of soya meal (IPB 1+CO+PM) ; and to use crystalline cholesterol (CC) instead of egg yolk (IPB 1+CO+CC). Twenty four Macaca fascicularis were used as animal model for three months adaptation followed by 12 months for four diet treatments. Parameters measured such body weight, waist circumference, trunk length, adiposity index, nutrient utilization, and plasma lipid profile every three months. This experiment used Completely Randomized Design with four treatments and six replications. Result showed that there were no significant differences found in morphometric parameters among the diet groups compared to one another or change from baseline. The nutrient (protein, fat and carbohydrate) consumption and the absorption were essentially the same for all four diet groups. The IPB 1+CO diet, the IPB $1+\mathrm{CO}+\mathrm{PM}$ diet and the IPB 1+CO+CC induced a similar atherogenic plasma lipid profile, with marked increases in total plasma cholesterol concentrations.
\end{abstract}

Keywords: atherogenic diet, crystalline cholesterol, powder egg yolk, pupa meal

Cite This Article: Dewi Apri Astuti, Dondin Sajuthi, Irma Herawati Suparto, Jay Kaplan, Sue Appt, and Thomas B. Clarkson, "The Development of Diets to Induce Atherogenic Lipid Profiles for Cynomolgus Monkeys in Their Country of Origin.” World Journal of Agricultural Research, vol. 2, no. 5 (2014): 247-251. doi: 10.12691/wjar-2-5-8.

\section{Introduction}

Cynomolgus monkeys (Macaca fascicularis) have become the most comprehensively characterized nonhuman primate model of human atherosclerosis (cite or monkey chapter). They have been the model of choice for a wide variety of studies involving the effect of nutrition, social behavior, reproductive status, depression, obesity, hypertension and a number of other presumed risk factors for coronary artery atherosclerosis. Additionally, the cynomolgus monkey model has been used extensively to evaluate the effects of drugs, hormones and lifestyle issues such as exercise and social isolation on the progression and regression of atherosclerosis. It was reported that non human primates are phylogenetically closer to humans and have similar lipid metabolism as humans, meanwhile rodents have less different lipid metabolism from those humans [3].
Studies of the natural history of human atherosclerosis in Western societies have provided clear evidence that by young adulthood (35 years of age) the majority of subjects have developed fatty streaks and plaques [9]. Consequently, for a nonhuman primate model to be of the most translational value in the evaluation of interventions intended for the treatment or prevention of atherosclerosis of adult human beings, the model should have a comparable amount of atherosclerosis to that seen in adult human beings when the intervention to be evaluated is initiated. To accomplish pre-experimental induction of atherosclerosis comparable to that of human beings in Western societies requires about 12 to 16 months of feeding a diet that induces a significantly atherogenic lipid profile. That long delay in starting an intervention is a major handicap for investigators working in a research intensive environment. A potential solution to this long delay is the development of atherogenic diets prepared from ingredients available in the monkey's country of origin allowing monkeys to be fed the diet for an extended time at the supplier's facility before exporting them to the 
user laboratory. The purpose of this communication is to describe such potential diets.

Investigators at Bogor Agricultural University Indonesia, Primate Research Center (IPB) made and reported on their initial attempts to develop an effective atherogenic diet [10]. The initial IPB atherogenic diet (IPB-1) was formulated from wheat flour, sugar, fresh egg yolk, beef tallow, coconut oil, corn meal, rice brand, soya meal, fish meal and trace minerals [1], while IPB-1 diet effectively induced an atherogenic lipid profile in cynomolgus monkeys, there were some inherent problems with its suitability to provide adequate nutrition for longterm feeding. A major problem was the use of coconut oil as the source of fat because this oil is very high in saturated fatty acids (86.50\%) such lauric, miristic and palmitic acids and low in polyunsaturated fatty acids (PUFAs) such as linoleic acid. This combination could result in a deficiency in essential fatty acids with longterm feeding. To correct the fatty acid deficiency, corn oil (CO) was added to the diet because it is high in PUFAs (64.68\%) with a high linoleic acid content (58\% of total PUFA) [5]. This diet is referred to as IPB 1+CO. Three additional variations of the IPB- $1+\mathrm{CO}$ diets were also created: 1) IPB 1+CO+PEY: dry powdered egg yolk (PEY) was used instead of fresh egg yolk; 2) IPB 1+CO+CC: the source of cholesterol (CC) was crystalline cholesterol instead of egg yolk and 3) IPB 1+CO+PM: a widely available and concentrated source of protein $(43 \%$ by weight), pupae meal (PM), was used instead of soya meal. Soya meal has a high content of isoflavones that can act as estrogen agonist or antagonist and could have atheroprotective effect on cynomolgus monkeys.

\section{Materials and Methods}

The design of the study is depicted in Figure 1. Twenty four adult male cynomolgus monkeys (Macaca fascicularis) were used and held at the animal facility of Primate Research Center, Bogor Agricultural University, Indonesia. Their range in age was 6-8 years estimated by dentition with average body weight $4-5 \mathrm{~kg}$. All monkeys were subjected to the standards provided by the Institutional Animal Care and Use Committee (ACUC). Animals were housed in individual cages positioned so that they can to see and hear each other. To ensure intake of their new diet treatments, the monkeys were fed IPB-1 atherogenic diet for 3 months and baseline measures were collected. They were fed 100-180 g per animal twice a day (08:00 am and $02.00 \mathrm{pm}$ ) plus one piece of $70 \mathrm{~g}$ banana (12:00 pm). Water was given ad libitum. The observations recorded were body weight, waist circumference, adiposity index (g of body weight/cm distance from the supra-sternal notch to the symphysis pubis), plasma lipid profile (TPC, HDL-C, triglyceride) and nutrient consumptions.

After three months adaptation, the monkeys were randomized into the four diet treatments (Table 1) stratified by total plasma cholesterol: high density lipoprotein cholesterol ration (TPC: HDL-C). The diet treatments were balanced for TPC: HDLC because large variability can exist in cholesterol absorption and plasma lipid and lipoprotein concentrations among cynomolgus monkeys consuming cholesterol rich diets. The four diets were fed for twelve months following repeat baseline measures every three months.

The composition of the initial IPB atherogenic diet 1 (IPB 1), diet-1 as IPB atherogenic diet 1 with essential fatty acids (IPB $1+\mathrm{CO}$ ), diet-2 as IPB atherogenic diet 1 with essential fatty acid and fresh egg yolk replaced by powdered egg yolk (IPB $1+\mathrm{CO}+\mathrm{PEY}$ ), diet-3 as IPB atherogenic diet 1 with essential fatty acid and soya meal replaced by pupae meal (IPB $1+\mathrm{CO}+$ pupa meal), and diet-4 as IPB atherogenic diet 1 with essential fatty acid and fresh egg yolk replaced by crystalline cholesterol (IPB $1+\mathrm{CO}+\mathrm{CC}$ ) as delineated in Table 1.

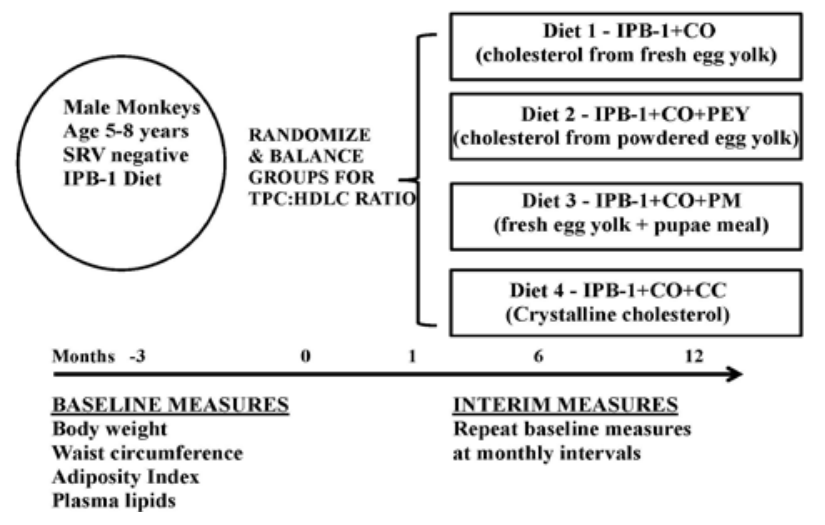

Figure 1. Schematic design of study

Table 1. Composition of the experimental diets

\begin{tabular}{|c|c|c|c|c|c|c|}
\hline Ingredients & $\begin{array}{c}\text { Diet } \\
\text { IPB1 }\end{array}$ & $\begin{array}{c}\text { Diet- } \\
1\end{array}$ & $\begin{array}{c}\text { Diet- } \\
2\end{array}$ & $\begin{array}{c}\text { Diet- } \\
3\end{array}$ & $\begin{array}{c}\text { Diet- } \\
4\end{array}$ \\
\hline Wheat flour & \multicolumn{5}{|c|}{$\%$ DM } \\
\hline Sugar & 42 & 40 & 43 & 40 & 43.8 \\
\hline Powdered egg yolk & 9 & 9 & 9 & 9 & 9 \\
\hline $\begin{array}{c}\text { Crystalline } \\
\text { cholesterol }\end{array}$ & 0 & 0 & 4 & 0 & 0 \\
\hline Beef tallow & 5 & 0 & 0 & 0 & 0.2 \\
\hline Coconut oil & 10 & 8 & 5 & 5 & 5 \\
\hline Corn oil & 0 & 2 & 2 & 2 & 2 \\
\hline Corn meal & 8 & 8 & 8 & 8 & 8 \\
\hline Rice bran & 3 & 3 & 6 & 3 & 7 \\
\hline Soya meal & 4 & 6 & 6 & 0 & 6.5 \\
\hline Pupa meal & 0 & 0 & 0 & 6 & 0 \\
\hline Fish meal & 5 & 5 & 5 & 5 & 5 \\
\hline Mineral mix & 1 & 1 & 1 & 1 & 1 \\
\hline Cellulose & 1 & 1 & 1 & 1 & 1.5 \\
\hline Vitamin mix & 1 & 1 & 1 & 1 & 1 \\
\hline
\end{tabular}

$\mathrm{CO}=$ corn oil, FEY = fresh egg yolk; $\mathrm{PEY}=$ powdered egg yolk; $\mathrm{CC}=$ Crystalline cholesterol, PM = pupa meal. Diet-1= IPB $1+\mathrm{CO}$; Diet-2= IPB 1+CO+PEY; Diet-3= IPB 1+CO+PM; Diet-4= IPB 1+CO +CC

Table 2. Nutrient composition of all atherogenic diets

\begin{tabular}{|c|c|c|c|c|c|}
\hline Nutrient & Diet IPB1 & Diet-1 & Diet-2 & Diet-3 & Diet-4 \\
\hline Dry matter (\%) & 88.0 & 86.69 & 85.39 & 88.41 & 83.88 \\
\hline Protein(\%) & 12.60 & 10.85 & 10.36 & 10.52 & 10.34 \\
\hline Lipids(\%) & 17.00 & 18.25 & 18.56 & 20.03 & 20.32 \\
\hline Carbohydrate (\%) & 57.00 & 48.00 & 49.57 & 50.50 & 49.82 \\
\hline Cholesterol (mg\%) & 81.12 & 92.00 & 81.00 & 86.00 & 83.30 \\
\hline
\end{tabular}

$\mathrm{CO}=$ corn oil, $\mathrm{FEY}=$ fresh egg yolk; $\mathrm{PEY}=$ powdered egg yolk; $\mathrm{CC}=$ Crystalline cholesterol, PM = pupa meal. Diet-1= IPB 1 + CO; Diet-2= IPB 1+CO+PEY; Diet-3= IPB 1+CO+PM; Diet-4= IPB 1+CO +CC

\subsection{Diet Analyses}

All diets were analyzed for their macronutrient composition following the procedures AOAC [2] and total energy by using bomb calorimeter. Cholesterol was measured by spectrophotometer by using enzymatic procedures. The nutrient compositions showed in Table 2. 


\subsection{Body Weight Assessments}

Body weight, waist circumference and trunk length were recorded on all monkeys monthly. Before measurements they were anesthetized with ketamine $\mathrm{HCl}$ (10-12 mg/kg, given intramuscular).

a. Body weight $(\mathrm{kg})$ - weight to the nearest gram

b. Waist circumference $(\mathrm{cm})$ - A flexible tape measure was placed around the monkey's abdomen at the level of the umbilicus to measure waist circumference $(\mathrm{cm})$. The measurements were always made in duplicate.

c. Trunk length $(\mathrm{cm})$ - Measure the distance $(\mathrm{cm})$ from the supra-sternal notch to the pubic symphysis, using calipers or non-flexible ruler and made by duplicate measurements. The data were convert from $\mathrm{cm}$ to meters.

$\mathrm{d}$. The adiposity index was calculated as the (g) of body weight/ divided by $(\mathrm{cm})$ distance from the supra-sternal notch to the symphysis pubis.

\subsection{Nutrient Absorption}

Food consumption was measured everyday by recording the weight of food fed to each animal (g) minus with the weight of food remaining after 24 hours. Dry matter food was measured by placing the food in a drying oven $105^{\circ} \mathrm{C}$ for 8 hours. Nutrient consumptions were calculated by multiplying dry matter intake by nutrient concentration of the diet (macro nutrients and fatty acids). Feces were collected using metabolic cages during the last seven days of the experiment. Ten percent of daily total fecal production from each animal was saved and frozen for proximate analysis. To evaluate the quality of diet and nutrient absorption, the nutrient in the feces was subtracted from nutrient consumption [6].

\subsection{Plasma Lipid Measurements}

Blood samples for plasma lipid measurements were collected by femoral venipuncture using standard techniques while the monkeys were sedated by Ketamine. Whole blood was centrifuged in order to get plasma and the lipid profiles were determined using a spectrophotometer (need more methods here - machine name etc.).

\subsection{Statistics}

The study used a randomized parallel arm design to allocate the monkeys to the four dietary groups.. All data are reported as mean \pm standard deviation. The data were analyzed using ANOVA comparing differences in the clinical measurements among the monkeys in the experimental diet groups. Duncan multiple range test was used. All statistical analyses were done using SPSS version 6 program.

\section{Result}

\subsection{Baseline Characteristics}

All animals adapted well to the IPB-1 diet during three months baseline (pre randomization) observations. Presented in Table 3 are the baseline data for all 24 monkeys. As expected from our previous study, the IPB-1 diet resulted in hypercholesterolemia while maintaining normal body weights and adipose index. There was considerable individual variation in the degree of hypercholesterolemia and food consumption as evidence by the rather high standard errors.

\subsection{Diet Effects on Morphometric Measures}

Morphometric measures of monkeys fed the original IPB-1 diet and the four modified diets are presented in a Table 4. There were no significant differences found among any of the diet groups compared to one another or change from baseline.

Table 3. Baseline study of monkeys after being fed IPB1 diet for 3 months

\begin{tabular}{|c|c|c|c|}
\hline \multicolumn{2}{|c|}{$\begin{array}{l}\text { Morphometric and Blood lipid } \\
\text { profile }\end{array}$} & \multicolumn{2}{|c|}{ Nutrient consumption } \\
\hline $\begin{array}{l}\text { Body weight } \\
\text { (kg) }\end{array}$ & $5.35 \pm 0.71$ & $\begin{array}{l}\text { Food consumption } \\
\qquad\left(\mathrm{g} \cdot \mathrm{d}^{-1}\right)\end{array}$ & $136.35 \pm 16.92$ \\
\hline $\begin{array}{l}\text { Waist } \\
\text { Cir.(cm) }\end{array}$ & $32.03 \pm 4.58$ & $\begin{array}{l}\text { Protein consumption } \\
\left.\text { (g.d } \text { d }^{-1}\right)\end{array}$ & $15.12 \pm 1.87$ \\
\hline $\begin{array}{l}\text { Trunk length } \\
\quad(\mathrm{cm})\end{array}$ & $30.47 \pm 0.83$ & $\begin{array}{l}\text { Carbohydrate } \\
\text { consumption }\left(\mathrm{g} \cdot \mathrm{d}^{-1}\right)\end{array}$ & $68.40 \pm 8.48$ \\
\hline $\begin{array}{l}\text { Adipose } \\
\text { index }\end{array}$ & $175,59 \pm 13.53$ & $\begin{array}{l}\text { Fat consumption } \\
\left(\text { g. } \mathrm{d}^{-1}\right)\end{array}$ & $20.40 \pm 2.53$ \\
\hline $\begin{array}{c}\text { Plasma } \\
\text { cholesterol } \\
(\mathrm{mg} \%)\end{array}$ & $419.73 \pm 15.41$ & $\begin{array}{c}\text { Cholesterol } \\
\text { consumption }\left(\mathrm{mg} \cdot \mathrm{d}^{-1}\right)\end{array}$ & $97.34 \pm 12.0$ \\
\hline $\begin{array}{c}\text { Plasma } \\
\text { Triglyceride } \\
\text { (mg\%) }\end{array}$ & $31.30 \pm 2.22$ & $\begin{array}{l}\text { Total energy } \\
\text { cons.(Cal/100g) }\end{array}$ & $468.51 \pm 28.90$ \\
\hline $\begin{array}{l}\text { Plasma HDL- } \\
\text { C (mg\%) }\end{array}$ & $78.70 \pm 12.98$ & & \\
\hline
\end{tabular}

Table 4. Monthly body morphometric on the monkeys fed experimental diets

\begin{tabular}{|c|c|c|c|c|}
\hline $\begin{array}{c}\text { Morphomet } \\
\text { ric }\end{array}$ & Diet-1 & Diet-2 & Diet-3 & Diet-4 \\
\hline $\begin{array}{c}\text { Body } \\
\text { weight (kg) }\end{array}$ & $5.66 \pm 0.47$ & $5.77 \pm 0.68$ & $5.25 \pm 1.08$ & $5.70 \pm 1.11$ \\
\hline $\begin{array}{c}\text { Waist Cir. } \\
\text { (cm) }\end{array}$ & $35.60 \pm 4.77$ & $32.93 \pm 4.87$ & $30.48 \pm 4.52$ & $34.40 \pm 7.90$ \\
\hline $\begin{array}{c}\text { Trunk } \\
\text { length (cm) }\end{array}$ & $30.30 \pm 1.52$ & $31.0 \pm 0.71$ & $29.80 \pm 0.83$ & $30.30 \pm 0.67$ \\
\hline $\begin{array}{c}\text { Adipose } \\
\text { index(g/cm) }\end{array}$ & $\begin{array}{c}187.38 \pm 20 . \\
51\end{array}$ & $\begin{array}{c}185.89 \pm 18 . \\
96\end{array}$ & $\begin{array}{c}176.25 \pm 35 . \\
80\end{array}$ & $\begin{array}{c}187.72 \pm 32 . \\
94\end{array}$ \\
\hline
\end{tabular}

$\mathrm{CO}=$ corn oil, $\mathrm{FEY}=$ fresh egg yolk; $\mathrm{PEY}=$ powdered egg yolk; $\mathrm{CC}=$ Crystalline cholesterol, $\mathrm{PM}=$ pupa meal. Diet-1= IPB $1+\mathrm{CO}$; Diet-2= IPB 1+CO+PEY; Diet-3= IPB 1+CO+PM; Diet-4= IPB 1+CO +CC

\subsection{Diet Effects on Nutrient Intake}

All four of the diets were palatable and food consumption was as expected. The average food consumption during the three months adaptation period was $136 \mathrm{~g} \mathrm{animal}^{-1} \mathrm{day}^{-1}$ and there were no increases or decreases after the monkeys were switched to the experimental diets. Food consumption averaged $139 \mathrm{~g}$ animal $^{-1}$ day $^{-1}$ during twelve months of observation. The nutrient (protein, fat and carbohydrate) consumption was essentially the same for all four diet groups (Table 5).

The percentage of dry matter, protein, fat and carbohydrate absorption was similar for all four diet groups (Table 5). Generally, all of the diets had good digestibility values and were absorbed well. 
Table 5. Nutrient consumption and absorption (\%) by cynomolgus monkeys fed experimental diets

\begin{tabular}{|c|c|c|c|c|}
\hline $\begin{array}{c}\text { Consumpti } \\
\text { on }\end{array}$ & Diet-1 & Diet-2 & Diet-3 & Diet-4 \\
\hline Food & $\begin{array}{c}139.67 \pm 11 . \\
17\end{array}$ & $\begin{array}{c}143.30 \pm 13 . \\
56\end{array}$ & $\begin{array}{c}134.69 \pm 14 . \\
68\end{array}$ & $\begin{array}{c}140.29 \pm 12 . \\
48\end{array}$ \\
\hline Protein & $13.07 \pm 1.05$ & $13.82 \pm 2.09$ & $12.02 \pm 1.27$ & $12.42 \pm 1.10$ \\
\hline Fat & $21.98 \pm 1.77$ & $25.38 \pm 2.40$ & $23.60 \pm 2.50$ & $22.23 \pm 1.98$ \\
\hline $\begin{array}{c}\text { Carbohydra } \\
\text { te }\end{array}$ & $57.80 \pm 4.65$ & $63.97 \pm 6.05$ & $57.86 \pm 6.14$ & $59.39 \pm 5.20$ \\
\hline $\begin{array}{c}\text { Cholesterol } \\
\text { (mg. } \mathrm{d}^{-1} \text { ) }\end{array}$ & $\begin{array}{c}110.79 \pm 8.9 \\
1\end{array}$ & $\begin{array}{c}108.92 \pm 10 . \\
31\end{array}$ & $\begin{array}{c}96.74 \pm 10.2 \\
6\end{array}$ & $97.04 \pm 8.63$ \\
\hline $\begin{array}{c}\text { Energy } \\
\text { (kcal.d }{ }^{-1} \text { ) }\end{array}$ & $\begin{array}{c}505.10 \pm 10 . \\
60\end{array}$ & $\begin{array}{c}485.10 \pm 43 . \\
10\end{array}$ & $\begin{array}{c}537.50 \pm 50 . \\
80\end{array}$ & $491.80 \pm 52$. \\
\hline \multicolumn{4}{|c|}{ Absorption (\%): } \\
\hline Dry Matter & $82.84 \pm 3.41$ & $81.12 \pm 1.67$ & $82.12 \pm 2.44$ & $80.63 \pm 2.28$ \\
\hline Protein & $70.99 \pm 5.40$ & $69.27 \pm 6.63$ & $71.42 \pm 3.62$ & $69.87 \pm 5.44$ \\
\hline Fat & $78.55 \pm 3.56$ & $73.07 \pm 3.51$ & $76.25 \pm 6.36$ & $74.40 \pm 4.67$ \\
\hline $\begin{array}{c}\text { Carbohydra } \\
\text { te }\end{array}$ & $89.40 \pm 2.39$ & $89.15 \pm 2.39$ & $90.24 \pm 1.80$ & $89.90 \pm 3.24$ \\
\hline
\end{tabular}

$\mathrm{CO}=$ corn oil, FEY = fresh egg yolk; PEY = powdered egg yolk; CC= Crystalline cholesterol, PM = pupa meal. Diet-1= IPB $1+$ CO; Diet-2= IPB 1+CO+PEY; Diet-3= IPB 1+CO+PM; Diet-4= IPB 1+CO +CC

\subsection{Diet Effects on Plasma Lipids and Lipoproteins}

The IPB $1+\mathrm{CO}$ diet, the IPB $1+\mathrm{CO}+\mathrm{PM}$ diet and the IPB 1+CO+CC induced a similar atherogenic plasma lipid profile, with marked increases in total plasma cholesterol concentrations and decreases in high density lipoprotein cholesterol concentrations (Table 6). The failure of the IPB 1+CO+PEY, prepared with dried egg yolk, to induce an atherogenic plasma lipid profile is unexplained. The experience at the Wake Forest Primate Center has been that if diets are made equivalent in cholesterol concentration there are no consistent or significant differences in the induction of an atherogenic lipid profile between crystalline cholesterol and the cholesterol contained in powdered egg yolk.

Table 6. Plasma lipid profile of cynomolgus monkey fed experimental diets during 12 months

\begin{tabular}{|c|c|c|c|c|}
\hline Parameters & Diet-1 & Diet-2 & Diet-3 & Diet-4 \\
\hline $\begin{array}{c}\text { Plasma } \\
\text { cholesterol }\end{array}$ & $406 \pm 39 \mathrm{a}$ & $200 \pm 3 \mathrm{~b}$ & $423 \pm 47 \mathrm{a}$ & $304 \pm 56 \mathrm{ab}$ \\
\hline $\begin{array}{c}\text { Plasma } \\
\text { triglyceride }\end{array}$ & $33.68 \pm 6.44$ & $40.96 \pm 4.62$ & $48.08 \pm 7.69$ & $59.64 \pm 13.46$ \\
\hline $\begin{array}{c}\text { Plasma HDL } \\
\text { Cholesterol }\end{array}$ & $46.55 \pm 5.07$ & $50.36 \pm 5.15$ & $34.58 \pm 4.40$ & $43.76 \pm 5.87$ \\
\hline
\end{tabular}

Values in row differing letters superscript, differ significantly at $\mathrm{p}<0.05$. $\mathrm{CO}=$ corn oil, $\mathrm{FEY}=$ fresh egg yolk; $\mathrm{PEY}=$ powdered egg yolk; $\mathrm{CC}=$ Crystalline cholesterol, PM = pupa meal. Diet-1= IPB $1+$ CO; Diet-2= IPB 1+CO+PEY; Diet-3= IPB 1+CO+PM; Diet-4= IPB 1+CO +CC

\section{Discussion}

The objective of the study was to identify a diet made from ingredients easily available in the monkey's country of origin (i.e. Indonesia) that would provide the nutrients required for long term health and at the same time induce an atherogenic plasma lipid profile. The availability of such diets would enable primate biologist located at primate centers in the cynomolgus monkey's country of origin to supply researchers with monkeys with induced atherosclerosis at a stage of progression comparable to that of human subjects.
Three of the diets induced a plasma lipid profile capable of inducing atherosclerosis in a reasonable period of time. The diet made with locally obtained dry powdered egg yolk was inadequate in cholesterol concentration to induce a sufficiently atherogenic plasma lipid profile, due to the variation of cholesterol concentration in the local product.

While the diet made with crystalline cholesterol induced the desired increase in plasma lipids, high quality crystalline cholesterol is difficult to obtain in the monkey's country of origin (importation of the crystalline cholesterol being cost prohibitive). The two remaining diets induced a desired atherogenic plasma lipid profile (IPB 1+CO and IPB 1+CO+PM). Between those two diets, atherosclerosis researchers for whom the monkeys would be fed before shipping them to the final research center would clearly prefer the diet in which the soya meal had been replaced with pupa meal (IPB $1+\mathrm{CO}+\mathrm{PM}$ ). The reason for that choice is because IPB $1+\mathrm{CO}$ contains soya meal and all soy products have a high content of isoflavones, known to be endocrine disrupters with major effects on cynomolgus monkeys.

Pupa meal is produced by silkworms and is readily available in Indonesia and surrounding countries. The protein and fat content of the pupa meal used in this study was $51 \%$ and $31 \%$, respectively. We found it to be a useful protein source which to substitute for soya protein. Meanwhile [4] reported that pupa of silkworm have 50\% protein and $37 \%$ of fat content.

Cynomolgus monkeys fed high sugar (57\%) high fat (18.50\%) diet during 33 weeks as animal model showed plasma lipid profile for TPC, HDL-cholesterol and

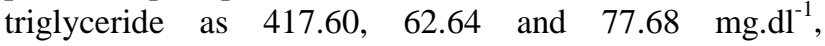
respectively [9]. Those data was comparable with this experiment to demonstrate that cynomolgus monkey can be used successfully to study the impact of diet on metabolic syndrome processes.

All four of the diets maintained the monkeys in good health for the duration of the feeding trial. Normal body weights were maintained during 12 months of observation. The nutrients uptake data provided evidence that the nutritional requirements of the monkeys was provided by the diets [8].

\section{Acknowledgement}

This research was granted by the Directorate General of Higher Education, Ministry of Education and Cultural Republic of Indonesia no.084/SP2H/Dit.Litabmas/V/2013. I would like to express my thanks to all colleagues who prepared diets and the veterinarian also animal technician in this study take care the animals during this research.

\section{Conflict of Interest Statement}

The authors declare that there is no conflict of interest relevant to this manuscript.

\section{List of Abbreviations}

BMI; CO; CC; HDL-C; IPB; PEY; PM; PUFA ;TPC 


\section{References}

[1] Astuti, D.A., Suparto, I.S., Sajuthi, D., Budiarsa, I.N. "Determination of nutrient digestibility of Cynomolgus monkey (Macaca fascicularis) fed with high starch diet: A preliminary study”, Hayati J. of Biosciences, 16 (4): 147-150, 2009

[2] AOAC. Official Methods of Analysis of the AOAC. AOAC Inc. Arlington. Virginia, 2005.

[3] Bergen, W.G., Mersman H.J. "Comparable aspects of lipid metabolism: impact on contemporary research and use of animal models”. J. Nutr., 135: 2499-2502, 2005.

[4] Finke, M.D. "Complete nutrient composition of commercially raised invertebrates as food for insectivores”, Zoo Biology, 21: 269-285, 2002

[5] Gervajio, G.C. Fatty acids and derivatives from coconut oil. In: Bailey's Industrial Oil and Fat Products, Sixth Ed. John Wiley \& Sons Inc. 2005.
[6] McDonald, P., Edwards, R.A., Greenhalgh, J.F.D. Animal Nutrition. $6^{\text {th }}$ ed. Longman Scientific and Technical, New York, 2002: 200-210.

[7] Mubiru,J.N., Forey, M.G., Higgins, P.B., Hemmat, P. and Rogers, J. "A Prelimanary report an the feeding of cynomolgus monkeys with a high sugar high fat diet for 33 weeks”. J Med. Primatol, 40 (5): 335-341, 2011

[8] Nutrient Requirement Council. NRC of Nonhuman Primates. $2^{\text {nd }}$ Rev Ed. The National Academies Press. Washington DC, 2003.

[9] Stills, H. F.Jr., Clarkson, T.B. Atherosclerosis. In: Sponaneous Models of Human Disease (E. J. Andrews, B. C. Ward, N. H. Altman, Ed.), Academic Press, New York, 1979; 70-79.

[10] Suparto, I.H., Oktarina, R., Astuti, D.A., Mansjoer, S.S., Sajuthi, D. "Blood lipid profile of cynomolgus monkey induced by high fat diet”. Indonesian Journal of Primatology, 7: 16-20, 2010. 